\title{
İdrar Yolu Enfeksiyonu Olan Yenidoğanların Değerlendirilmesi
}

\author{
Evaluation of Newborns with Urinary Tract Infection
}

\section{Ebru ŞAHİN ${ }^{1}$, Nihan Uygur KÜLCÜ ${ }^{2}$, Züleyha Aysu SAY ${ }^{2}$}

1. Şehit Prof. Dr. İlhan Varank Ĕgitim ve Araştırma Hastanesi, Çocuk Sağlı̆̆ ve Hastalıkları, İstanbul, Türkiye

2. Zeynep Kamil Kadın ve Çocuk Hastalıkları Ĕgitim ve Araştırma Hastanesi, Çocuk Să̆lığı ve Hastalıkları, İstanbul, Türkiye

\section{$\ddot{O Z Z E T}$}

Amaç: Çocuklukta geçirilen idrar yolu enfeksiyonu (IYE), erişkin çağda böbrek yetmezliğinin en önemli sebeplerinden biridir. Zamaninda tanınip, uygun tedavi edilen enfeksiyon, renal hasar riskini azaltabilir. Çalışmamızda hastanemizde IYYE tanısıla tedavi edilen yenidoğanlart retrospektif olarak değerlendirmeyi, tanı ve tedavi konusundaki verilerimizi klinik pratiğimizde yardımcı ve yol gösterici olarak kullanmayı amaçladık.

Gereçler ve Yöntem: Bu araştırmaya, Ocak 2009- Ekim 2012 tarihleri arasında Zeynep Kamil Kadın ve Cocuk Hastalıklar Ĕgitim ve Araştırma Hastanesi Yenidoğan Yoğun Bakım-2 Ünitesi'ne, idrar yolu enfeksiyonu tanisiyla yatirllan ya da yatırldiktan sonra idrar yolu enfeksiyonu tanisı alan 137 yenidoğan hasta dâhil edildi. Tüm hastaların demografik özellikleri, fizik muayene bulgularl, laboratuvar değerleri ve tedavi yöntemleri değerlendirildi.

Bulgular: Calısmamızdaki 137 hastanın \%78,8'i erkek, \%21,2'si kızdl. Hastaların başvuru semptomları sırasıyla; uzamıs sarılık $(\% 38,7)$, ateş $(\% 28,5)$, emmeme $(\% 28,5)$, kusma $(\% 13,1)$, huzursuzluk $(\% 10,2)$, dehidratasyon $(\% 10,2)$, letarji $(\% 6,6)$, kilo alamama $(\% 4,4)$, idrar yaparken ağlama $(\% 2,9)$, konvülziyon $(\% 1,5)$, ishal $(\% 1,5)$ ve batın distansiyonu $(\% 0,7)$ idi. İdrar kültüründe üreven en sık patojenler; E.coli (\%54), Klebsiella spp. $(\% 10,2)$, Enterobakteriacea spp $(\% 9,5)$ ve ESBL(+) E.coli $(\% 7,3)$ idi. En çok direnç geliștirilen antibiyotik ampisilindi. Ampisiline en fazla direnç gösteren patojen E.coli $(\% 76,3)$ 'ydi.

Sonuç: İdrar yolu enfeksiyonu, özellikle yenidoğan ve süt çocuklarında atlanmaması gereken ve ciddi sonuçları olan bir enfeksiyondur. Oluşabilecek komplikasyonların önüne geçilmesi, antibiyotik seçimi, uzun süreli izlem ve görüntüleme yöntemlerinin yönetimine bağlıdır.

Anahtar Kelimeler: yenidoğan, idrar yolu enfeksiyonu, antibiyotik direnci

\section{ABSTRACT}

Objective: : Childhood urinary tract infection (UTI) is one of the most important causes of renal failure in adult age. Fast and correct recognition and appropriate treatment of urinary tract infections during neonatal period may reduce the risk of renal damage. In our study; we aimed to evaluate newborns with UTI who were hospitalized in our neonatal ward retrospectively, and to use our findings in our clinical and treatment practice.

Material and Methods: We enrolled 137 neonates who were hospitalized with the diagnosis of UTI or diagnosed as UTI after hospitalization in Zeynep Kamil Gynecologic and Pediatric Training and Research Hospital NICU-2 between January 2009 - October 2012. All patients' demographic characteristics, physical examination findings, laboratory values, and treatment were evaluated retrospectively.

\section{iletişim:}

Sorumlu Yazar: Ebru SAHIN

Adres: Şehit Prof. Dr. İlhan Varank Eğt. ve Arş. Hast., Emek Mah. Namık Kemal Cad. No:54, 34785 Sancaktepe, İstanbul, Türkiye Tel: +90 (216) 6063300

E-Posta: ebruguneysahin@hotmail.com

Makale Geliş: 24.07.2018

Makale Kabul: 26.07.2018

DOI: http://dx.doi.org/10.16948/zktipb.447389
Results: Of the 137 neonates included to the study 78,8\% were male and 21,2\% female. Presenting symptoms of patients was prolonged jaundice $(38,7 \%)$, fever $(28,5 \%)$, poor sucking $(15,3$ $\%)$, vomiting $(13,1 \%)$, restlessness $(10,2 \%)$, dehydration $(10,2$ $\%$, lethargy (6,6\%), weight loss $(4,4 \%)$, crying during the voiding $(2,9 \%)$, convulsion (1,5\%), diarrhea (1,5\%), abdominal distantion (0,7\%) respectively. Most frequent pathogens cultured in urine was E. coli (54\%), Klebsiella spp. (10.2\%), Enterobacteriacea (9,5\%), ESBL (+) E. coli (7,3\%) respectively. The most common antibiotic resistance was to ampicilline. The most resistant pathogene to ampisiline was E.coli.

Conclusion: Urinary tract infection is an infectious disease that should not be missed in newborns and infants and has serious consequences. Prevention of complications that may occur depends on the management of antibiotic selection, long-term follow-up and imaging methods.

Keywords: newborn, urinary tract infection, antibiotic resistance

\section{GİRIŞ}

İdrar yolu enfeksiyonu (IYE), steril olan üriner sistemin enfekte olması sonucu oluşmaktadı (1). IYYE'nu yaşamın ilk üç ayında erkek bebeklerde daha sık görülür. Bunun nedeni, erkek çocuklarda üriner sistemin doğumsal anomali siklığının yüksek olmasıdır (2). Yenidoğan döneminde term yenidoğanlarda İYE sıklığı, \%0,1-1 olup, çeşitli çalışmalarda bu sıklığın düşük doğum ağırlıklı bebeklerde \%10'a, prematürelerde ise $\% 25$ 'e kadar arttığ1 gösterilmiștir(burada birkaç kaynak vermen uygun). IYYE prevelans1 ateşli yenidoğanlarda $\% 13,6$ - 14 , süt çocuklarında ise $\% 5,3$ olarak bildirilmiștir $(3,4)$.

İlk İYE'ndan sonra erkek çocukların \%20-30'unda, kız çocukların ise \%40-60'1nda enfeksiyonun tekrarlama riski bulunmaktadır (5). İlk enfeksiyondan sonra hastaların; bir y1l içinde \%30'unun, beș y1l içinde ise \%50'sinin tekrar IYYE geçirdiği gösterilmiștir. Geçirilen her IYYE'ndan sonra yineleme riskinin daha da arttığı bildirilmektedir (6).

Yenidoğan döneminde IYY semptomları çok belirgin olmadığ 1 gibi, spesifik de değildir. Tanı koymak için hekimin şüphe eşiğinin düşük olması gerekir. Yenidoğan döneminde; ateş ya da hipotermi, emmeme, kusma, ishal, uzamış yenidoğan sarılığı, irritabilite, letarji, asidoz, abdominal distansiyon, kilo alamama, huzursuzluk, idrar yaparken ağlama, konvulziyon gibi klinik bulgular görülebilir (7).

Yeni tanısal yaklaşımlar ve etkili antibiyotiklerin kullanımıyla mortalite hemen hemen sifira inmekle birlikte, çocukluk çağında geçirilen IYYE, halen erişkin yaşlardaki böbrek yetmezliğinin en önemli 
sebeplerinden birini oluşturmaktadır. Zamanında tan 1 konularak tedavi edilen olgularda, enfeksiyona bağlı gelişen renal hasar riski azaltılabilir ve geç dönemde gelişebilecek hipertansiyon, ilerleyici böbrek yetmezliği gibi ciddi komplikasyonlar önlenebilir (5).

IYYE'na en s1k Gram negatif basiller neden olur (8). İdrar yolu enfeksiyonu etkeni olan Enterobacteriaceae ailesi üyeleri; Escherichia, Klebsiella, Enterobakter, Citrobakter, Proteus, Providencia, Morganella, Serratia ve Salmonella'dır. Bunlar arasinda ilk sıray \% 75-90 siklıkla E.coli alır (9). İdrarda üretilen E.coli, dışkı florasındaki E.coli ile serolojik olarak aynıdır (10). İlk İYE'nda etken büyük olas1lıkla E.coli iken, sonraki enfeksiyonlarda bu olasılık giderek azalmaktadır (11).

Seçilecek tedavi, hastanın daha önce kullandığı antibiyotikler, ilaç alerjisi, toplumdaki direnç göz önüne alınarak düzenlenmelidir. Yenidoğan döneminde hastaların genel durumları çok kısa sürede bozulabileceğinden, hastanede parenteral tedavi ile izlenirler. Parenteral tedavi 7-10 güne tamamlanır (7). Sepsis ve menenjit birlikteliği olabilir. Yeni araştırmalar iki aydan küçük bebeklerde kısa süreli parenteral tedavi sonrasinda, oral tedavi ile devam edilebileceğini öne sürmektedirler (12). Yenidoğanın böbrek fonksiyonlarını gösteren parametreler ve elektrolit düzeyleri bilinmelidir. Tedaviden 24-48 saat sonra idrar kültürü steril hale gelir. Kültür sonuçlarına göre antibiyotik değişimi yapılabilir.

Çalışmamızda IYYE tanısı alan yenidoğanların; demografik özelliklerini inceledik, laboratuvar bulguları ve tedaviye yanıtlarını değerlendirdik. Antibiyotik seçiminde klinisyene yol gösterici olmayı hedefledik.

\section{GEREÇ ve YÖNTEM}

Çalışmamıza, Ocak 2009- Ekim 2012 tarihleri arasında Zeynep Kamil Kadın ve Çocuk Hastalıklar1 Eğitim ve Araştırma Hastanesi Yenidoğan Yoğun Bakım-2 Ünitesi'ne idrar yolu enfeksiyonu tanısıyla yatırılan ya da yatırıldıktan sonra idrar yolu enfeksiyonu tanısı alan 137 yenidoğan hasta dâhil edildi. Hasta dosyaları incelenerek demografik özellikler, semptomlar, fizik muayene bulgular1, laboratuvar değerleri, ve tedavi seçimleri değerlendirildi.

Çalışmaya alınan tüm hastalardan idrar kültürü steril şartlarda, suprapubik aspirasyon (SPA) veya üretral kateterizasyon alındı. Kırklık büyütmede her mikroskop sahasında 5 veya daha fazla lökosit görülmesi 'piyüri', 5 veya daha fazla eritrosit görülmesi ‘hematüri' olarak değerlendirildi. Mesane kateterizasyonu ile alınan idrar kültürlerinde $>10.000$ koloni/ml, suprapubik alınan örneklerde ise tek koloni üremesi idrar yolu enfeksiyonu tanısinda anlamlı kabul edildi. Daha az sayıda koloni oluşumu veya birden fazla mikroorganizmanın üremesi bulaş olarak kabul edildi.

Tam kan sayımı, C-reaktif protein düzeyi değer- lendirildi. İlk başvuruda bakılan lökosit sayısının 20.000/mm3, CRP değerinin $0.5 \mathrm{mg} / \mathrm{dl}$, üzerinde olması anlamlı olarak kabul edildi.

IYYE tanısıyla izlenen hastaların kaç gün tedavi edildiği, hangi antibiyotiğin kullanıldığı, başlanan tedaviye yanıt olup olmadığı değerlendirildi.

Çalışmada elde edilen bulgular değerlendirilirken, istatistiksel analizler için SPSS (Statistical Package for Social Sciences) for Windows 15.0 programı kullanıldı. Çalışma verileri değerlendirilirken tanımlayıcı istatistiksel metodların (frekans) yanısıra niteliksel verilerin karşılaştırılmasında Ki-Kare testi ve Fisher's Exact Ki-Kare testi kullanıld1. Anlamlılık $\mathrm{p}<0.05$ düzeyinde değerlendirildi.

\section{BULGULAR}

Çalışma Ocak 2009- Ekim 2012 Tarihleri arasinda toplam 137 yenidoğan hasta üzerinde yapıldı. Hastalara ait demografik bilgilerin dağılımı Tablo 1 'de görülmektedir.

Tablo 1: Demografik Özellikler.

\begin{tabular}{|c|c|c|c|}
\hline & & $\mathrm{n}$ & $\%$ \\
\hline \multirow{2}{*}{ Cinsiyet } & $\mathrm{KIZ}$ & 29 & 21,2 \\
\hline & ERKEK & 108 & 78,8 \\
\hline \multirow{3}{*}{ Yaşı } & 0-3 GÜN & 12 & 8,8 \\
\hline & 4-7 GÜN & 17 & 12,4 \\
\hline & 8-28 GÜN & 108 & 78,8 \\
\hline \multirow{2}{*}{ Doğum Şekli } & NSD & 70 & 51,1 \\
\hline & Sezaryen & 67 & 48,9 \\
\hline \multirow{2}{*}{ Doğum Kilosu } & $<2500$ & 27 & 19,7 \\
\hline & $\geq 2500$ & 110 & 80,3 \\
\hline \multirow{2}{*}{ Gestasyon Yaşı } & Term & 90 & 65,7 \\
\hline & Preterm & 47 & 34,3 \\
\hline Antenetal Hidronefroz Tanısı & Var & 5 & 3,6 \\
\hline Annede Ek Hastalık & Var & 12 & 8,8 \\
\hline Maternal İYE Öyküsü & Var & 41 & 29,9 \\
\hline Ailede Böbrek Hastalığı & Var & 3 & 2,2 \\
\hline
\end{tabular}

Semptomların dağılımına bakıldığında, en s1k $\% 38,7$ ile uzamış sarılık görüldü. Bunu \%28,5 ile ateş izlerken, hastaların \%15,3'ünde emmeme, \%13,1'inde kusma, \%10,2'sinde huzursuzluk, $\% 10,2$ 'sinde dehidratasyon, \%6,6'sinda letarji, $\% 4,4$ 'ünde kilo alamama, \%2,9'unda idrar yaparken ağlama, \%1,5'inde ishal, \%1,5'inde konvulziyon ve sadece 1 bebekte $(\% 0,7)$ batında distansiyon tespit edildi (Şekil-1). Term ve preterm bebeklerin semptomları karşılaştırıldığında ateş görülme oranı $(\% 33,3)$ preterm bebeklerden $(\% 19,1)$ daha yüksek olmakla birlikte bu farklılık anlamlılığa yakın ancak istatistiksel olarak anlamlı değildi. Diğer semptomların görülme oranları arasında istatistiksel olarak anlamlı bir fark yoktu. Cinsiyete göre semptomların görülme sıklığı değişmemekteydi.

Hastaların \%77,4'ünde eşlik eden hastalık yoktu. Hastaların \%9,5'inde sepsis, \%2,9'unda bronşiolit veya pnömoni, $\% 2,2$ 'sinde menenjit, $\% 2,2$ 'sinde kardiyovasküler hastalık, \%1,5'inde direkt hiper- 


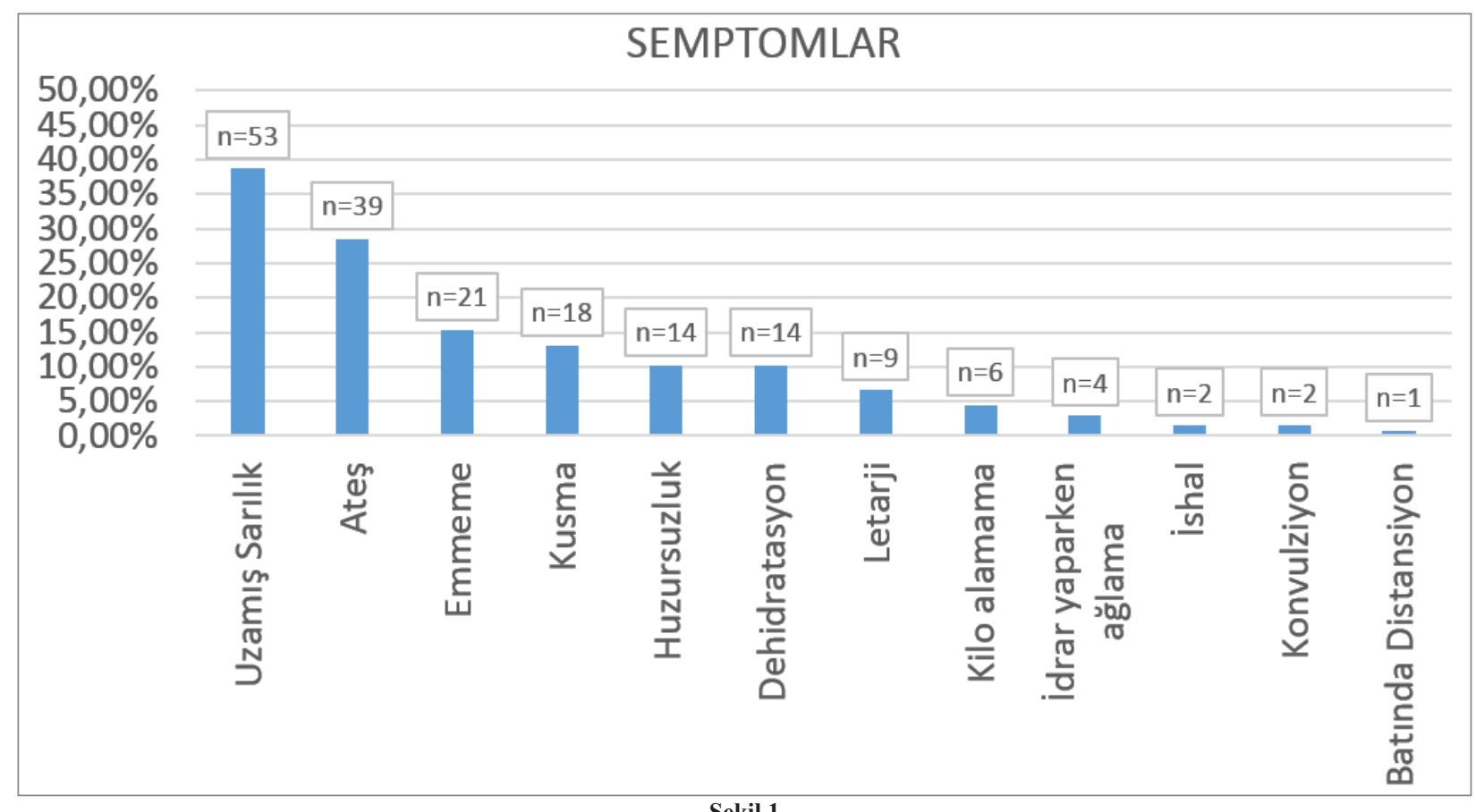

Şekil 1

bilirubinemi, \%1,5'inde nazofarenjit, \%1,5'inde metabolik hastalik, \%1,5'inde endokrin hastalik, $\% 1,5$ 'inde hematolojik hastalık ve 1 bebekte $(\% 0,7)$ gastrointestinal sistem hastalığı bulunmaktayd.

Sifır-3 gün arasında hastaneye yatan yenidoğanların \%12'sinde, 4-7 gün arasında yatanların \%10'unda ve 8-28 gün arasında yatanların \%78'inde maternal IYYE öyküsü mevcuttu.

Hastaların \%69,3'ünden mesane sonda kateterizasyonu ile, \%30,7'sinden SPA yöntemiyle idrar kültürü alındı. Hastaların \%15,3'ünden hastaneye yatıştan önce, \% 74,5'inden yatışında ve \% 10,2'sinden yatışından sonra idrar kültürü alındı. Hastaların \%37,2'sinde idrarda lökosit, \%8,8'inde nitrit, $\% 8$ 'inde lökosit esteraz sonucu pozitifti.

İdrar kültürü sonucunda hastaların; \%54'ünde E. coli, \%10,2'sinde Klebsiella spp., \%9,5'inde Enterobakter, \%7,3'ünde ESBL+E.coli, \%3,6'sinda D grubu $\beta$ hemolitik Streptokok, \%1,5'inde Candida albicans, \%1,5'inde ESBL+Klebsiella, \%0,7'sinde Proteus, \%0,7'sinde Psödomonas ve \%0,7'sinde MRSA, \%10,2'sinde diğer mikroorganizmalar (MSSA, Stafilakokus agalactia, Haemophilius, Koagulaz negatif Stafilokok, MRSE, Citrobacter, Streptokokus agalactia, Serratia) üredi. İdrar kültüründe üreyen mikroorganizmaların dağılımı Şekil-2 de verilmiştir.

Alınan kan kültürlerinin \%9,5'inde üreme oldu. Hastalardan endikasyon dahilinde \%24,1'inden BOS kültürü gönderildi ancak hiçbirinde üreme tespit edilmedi.

Hastaların \%3,6'sında lökositoz, \%24,1'inde CRP pozitifliği, \%8'inde böbrek fonksiyon testlerinde bozukluk vardı. Hastaların \%85,4'ünün elektrolitleri normal, \%14,6'sinin patolojikti. Kan gaz1 bak1lan $56(\% 40,9)$ hastanın \%17,9'unda asidoz mevcuttu.
Ateș olan hastalarda CRP pozitifliği görülme oranı $(\% 46,2)$, ateşi olmayan olgulardan $(\% 15,3)$ istatistiksel olarak ileri düzeyde anlamlı yüksek bulundu $(\mathrm{p}<0.01)$. Ateşi olan ve olmayan hastalarda lökositoz saptanmasinda istatistiksel olarak anlamlı bir fark bulunmadi.

Uzamış sarılığı olan hastaların CRP pozitifliği görülme oranı $(\% 7,5)$, uzamış sarılığı olmayanlardan $(\% 34,5)$ istatistiksel olarak ileri düzeyde anlamlı düşük bulundu $(\mathrm{p}<0.01)$.

Term bebeklerde lökosit esteraz pozitifliği görülme oran1 $(\% 12,2)$, preterm bebeklerden $(\% 0)$ istatistiksel olarak anlamlı düzeyde yüksekti. Cinsiyete göre lökosit esteraz pozitifliği görülme oranları arasında istatistiksel olarak anlamlı bir fark bulunmadı.

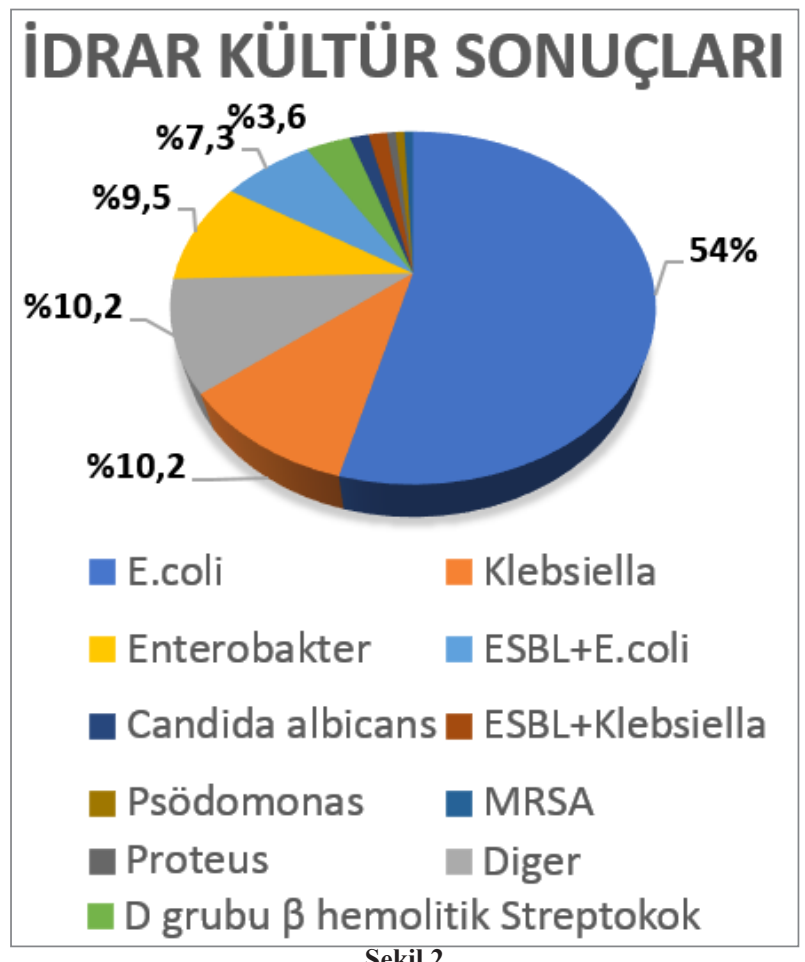


Başvuru yıllarına göre idrar kültüründe üreyen etkenler arasında istatistiksel olarak anlamlı bir fark yoktu. Başvuru yıllarına göre idrar kültüründe ESBL+E.coli görülme sıklığı arasında anlamlılığa yakın olmakla birlikte istatistiksel olarak anlamlı bir fark bulunmadi. Bununla birlikte 2009 ve 2010 yıllarında başvuran hastalarda ESBL+E.coli üremesi görülmezken, 2011 yılında ESBL+E.coli üreme s1klığının $\% 12,8$ ve 2012 y1lında \%10,3 olması dikkat çekicidir. Cinsiyete göre, idrar kültüründe E.coli, Klebsiella, Enterobakter ve ESBL+E.coli etkenlerinin üreme oranları arasında istatistiksel olarak anlamlı bir farklilık bulunmadı. İdrar kültüründe üreyen etken ile, CRP yüksekliği, lökositoz ve anormal böbrek fonksiyon testi görülme oranları arasında bir korelasyon saptanmadi.

Yüzotuzbeş hastanın kültür antibiyogramı değerlendirildiğinde; \%25,2 sefuroksim aksetil, \%36,3 amoksisilin-klavulonat, \%25,9 trimetoprim-sulfometoksazol, \%15,6 nitrofurantoin, \%69,6 ampisilin, $\% 5,9$ siprofloksasin, $\% 19,3$ seftriakson, $\% 30,4$ sefazol, \%14,8 gentamisin direnci saptandi.

Otuzaltı hastanın kültür antibiyogramında imipenem direnci bakıldı, \%5,6 direnç saptandı. Linezolid, vankomisin ve teikoplenine direnç saptanmadi.

Yenidoğanların \%28,5'ine ampisilin+aminoglikozid, \%24,1'ine sefotaksim, \%18,2'sine sefuroksim aksetil, \%15,3'üne meropenem, \%3,6'snna ampisilin, \%2,2'sine aminoglikozid, \%1,5'ine sefotaksim+ampisilin, \%1,5'ine sefoperazon, \%1,5'ine teikoplenin, \%1,5'ine flukonazol, \%1,5'ine sefazol ve 1 hastaya vankomisin tedavisi uyguland. Hastaların \%38'inde kültür antibiyogram sonucuna göre antibiyotik değişimi yapıldı. Hastaların \%88,3'ünün ilk, $\% 8,8$ 'inin ikinci ve \%2,9'unun üçüncü idrar kültür sonucu sterildi.

E.coli'nin sefuroksim aksetil $(\% 12,2)$, trimetoprim-sulfametoksazol $(\% 18,9)$, seftriakson $(\% 6,8)$, sefazol $(\% 17,6)$ ve gentamisin direnç oranı $(\% 8,1)$ E.coli dişı etkenlere göre istatistiksel olarak ileri düzeyde anlamlı düşük bulundu $(\mathrm{p}<0.01)$.

Y1llara göre sefuroksim aksetil, amoksisilin-klavulonat, trimetoprim-sulfametoksazol, ampisilin, seftriakson, sefazol, gentamisin, sefoperazon ve sefepim antibiyotiklerine direnç görülme oranları arasında istatistiksel olarak anlamlı fark bulunmadi.

\section{TARTIŞMA}

İnfant dönemde geçirilen IYYE, böbrek hasarı neticesinde, ileri yaşlarda son dönem böbrek yetmezliği ve hipertansiyona yol açabileceğinden tanı ve tedavisi önemlidir. Genel kanı; ilk IYYE'ndan sonra üriner sistemin görüntülenmesi, enfeksiyonun tekrarlama riski nedeniyle yakın takip yapılması yönündedir.

İnfant dönemin ilk üç ayı, IYYE’nun erkek çocuklarda daha sık görüldügü bilinmektedir. Bonadio ve ark (13) çalışmalarında, yenidoğan döneminde İYE geçiren hastaların \%73'ünü erkeklerin oluşturduğunu saptamıştır. Bizim çalışmamızda da benzer olarak, hastalarımızın \% 78,8'ini erkekler, \%.21,2'sini kızlar oluşturdu.

Çalışmamızda hastalarımızın \%29,9'unda maternal IYE öyküsü mevcuttu. Emamghorashi ve arkadaşları (14) özellikle son trimestrde maternal IYYE geçirmenin, yenidoğanda İYE görülme riskini arttığını tespit etmişlerdi. Enfeksiyonu artıran bir neden olarak kabul edilmesi yanısıra, maternal kaynaklı enfeksiyonların postnatal ilk hafta içinde ortaya çıkması, maternal IYYE öyküsü olan hastalarımızın \%78'ininse 8-28 gün içinde başvurmuş olması kesin predispozisyon yarattığı konusunda şüphe oluşturmaktadır.

Çalışmamızda başvurudaki en sık semptomları sırasıyla; \%38,7 uzamış sarılık, \%28,5 ateş VE \%15,3 emmeme olarak saptadık. Arıkan ve arkadaşları (15) çalışmalarında bu oranları sırasıyla; $\% 55, \% 42, \% 66$ olarak saptamıştır. Yine Bıyıklı ve arkadaşları (16) çalışmalarında IYYE'larının en sık geliş şikâyetinin hiperbilirubinemi olduğunu, term bebeklerde anlamlı olarak daha yüksek rastlandığını bildirmiştir. Bizim çalışmamızda da uzamış sarılık \%38,7 oranıyla en sık başvuru nedeniydi. Bu durum uzamış sarılıkla başvuran hastalarda idrar kültürünün alınmasını gerekli kılmaktadır.

Arıkan ve arkadaşları (15) eşlik eden hastalık sıklığını; \%8 menenjit, \%12 pnömoni, $\% 6$ omfalit olarak saptamıştır. Çalışmamızdaki 137 IYE tanılı hastaya; $\% 9,5$ sespis, $\% 2,9$ pnömoni-bronşiolit, $\% 2,2$ menenjit, \%1,5 nazofarenjit eşlik etmekteydi. Bu durum yenidoğan döneminde IYYE'nun diğer hastalıklarla komorbidite gösterebileceğini, şüphe durumunda idrar kültürü incelemesi yapılması gerekliliğini göstermektedir.

Bıyıklı ve arkadaşları (16) klinik olarak ürosepsis düşündükleri 4 hastanın kan ve idrar kültüründe farklı mikroorganizma tespit etmişlerdir. Bizim çalışmamızda da eş zamanlı tüm hastalardan alınan kan kültürlerinin 13'ünde üreme olmuştu. Saptanan mikroorganizmalar, idrar kültüründe üreyen mikroorganizmalardan farklıydı. Cinsiyete göre IYYE'nda sepsis görülme sıklığında anlamlı bir fark bulunmadı. IYYE tanılı hastalardan eş zamanlı kan kültürü alınmasının yararlı olacağı görüşündeyiz. Yine aynı çalışmalarında preterm hastaların \%41'inde, term bebeklerin \%69'unda piyüri saptamışlar. Term bebeklerde piyüriyi daha yüksek bulmuşlar ve tanıya yönlendirmekte faydalı olacağı sonucuna varmışlardır. Bizim çalışmamızda, term hastaların \%41, 1 'inde, preterm hastaların \%29,8'inde piyüri vardı. Gestasyonel yaşa göre piyüri saptanma oranları arasında fark yoktu. Lökosit esteraz pozitifliği görülme oran1 term bebeklerde daha yüksekti. Rahman ve arkadaşları (17) çalışmalarında, sonda ile aldıkları idrarın, mikroskopisinde bir tane bile lökosit bulunması durumunda, hastalardan sonda yöntemiyle idrar kültürü göndermişler. Kültür gönderilen 35 hastanın \%71,4'ünde üreme saptamamışlar. Yenidoğan döneminde piyüri saptanmasının IYYE tanısında kesin yol gösterici olamayacağı kanısına varmışlardır. Bizim çalışmamızda da hastaların \%62,8'inde piyüri 
saptanmadı. Yenidoğan döneminde piyürinin, lökosit esteraz ve nitrit pozitifliğinin olmaması klinisyeni IYE tanısından uzaklaştırmamalıdır.

İdrar yolu enfeksiyonu tanısında idrar kültürü altın standarttır. Yenidoğan döneminde torba ile alınan idrar kültürünün yalancı pozitiflik oranının yüksek olduğunu gösterilmiştir (18). Semerci ve arkadaşlar1 (19) İYE olduğunu düşündükleri 1-15 ay arası 79 hastadan torba ve SPA ile eş zamanlı olarak alınan idrar kültür sonuçlarını karşılaștırmıșlar. Torbayla idrar kültürünün özgüllüğünü $\% 13$, duyarlılığını $\% 86$, pozitif prediktif değerini $\% 9$, negatif prediktif değerini $\% 90$ olarak bildirmişlerdir. İlk planda parenteral antibiyotik tedavisi almasi gereken yenidoğanlar için tanının kesinleştirilmesinin gereği aşikardır. Biz kliniğimizde yenidoğan dönemi için SPA ve kateterizasyon yöntemlerinin daha güvenilir olduğunu düşünmekte ve bunları uygulamaktayız. E.coli diş1 gram negatif etkenlerin, erkek yenidoğanlarda daha s1k olduğunu tespit eden Honkinen ve arkadaşlarına (20) nazaran, çalışmamızda, etken mikroorganizma ile cinsiyet korelasyonu arasinda anlamlı bir ilişki saptayamadık.

Chamdine ve arkadaşları (21) uzamış sarılıklı yenidoğanların \%21,1'inde IYE saptadıkları çalışmalarında, en sık üreyen patojenleri sırasıly; $\% 46,8$ ile Klebsiella spp., \%37,5 ile E.coli olarak bulmuşlardır. Bizim çalışmamızda uzamış sarılığı olan hastalarda en s1k E.coli $(\% 50,9)$ ikinci s1kl1kta Klebsiella spp. (\%18.9) üredi. Klebsiella spp. uzamış sarılığ 1 olan hastalarda diğer semptomlarla başvuran hastalara göre anlamlı olarak daha yüksek saptandı.

Son zamanlarda artan ampisilin ve aminoglikozid dirençli E.coli türleri, ampirik tedavinin yeniden gözden geçirilme fikrini doğurdu. Çalışmamızda, yıllara göre en sık tespit edilen patojenin hala E.coli olduğunu gördük. E.coli'nin ampisilin direncinin yıllar içinde anlamlı bir yükseliş göstermediğini fakat en çok direnç geliștirilen antibiyotiğin ampisilin olduğunu saptadık. Veriler değerlendirildiğinde son yıllarda sefuroksim aksetil, ampisilin ve gentamisine olan direncin istatistiksel olarak anlamlı yükseldiği bulundu. Yu-Jie ve arkadaşları (22) çalıșmalarında E.coli ve Klebsiella'nın ampisiline ve çoğu sefalosporine yüksek dirençli $(\geq \% 85)$ olduğunu saptamışlardır. Bizim çalıșmamızda E.coli’nin ampisilin direncini \%64,9 idi. Antibiyotik direnci nedeniyle 52 (\%38) hastada antibiyotik değişimine gittik. E.colilerin sefuroksim aksetil, seftriakson ve sefazol dirençleri diğer etkenlerle karşılaştırıldığında anlamlı olarak daha düşüktü. Tedavide bu antibiyotiklerin ampirik olarak başlanması tedavi şansını artıracaktır.

Yenidoğan döneminde geçirilen IYYE tekrarlay1c1 özellikte olabilir. Hamburger (23) yenidoğan IYYE'nunda nüks oranını $\% 25$ olarak bulmuştur. Küçük yaşta geçirilen IYYE renal skarlanma oranını artırdığından uzun dönem izlem önemlidir. Üriner anomali tespit ettiğimiz hastalarımızı uzun vadeli takip için çocuk nefroloji polikliniğine yönlendirdik. Üriner anomalisi olmayan hastaları Yenidoğan Yoğun Bakım-2 Ünitesi polikliniğinde uzun vadeli takibe aldık.

\section{SONUÇ}

Sonuç olarak idrar yolu enfeksiyonu, özellikle yenidoğan ve süt çocuklarında atlanmaması gereken ve ciddi sonuçları olan bir enfeksiyondur. Oluşabilecek komplikasyonları önlemek için uygun antibiyotik ile tedavi, uzun süreli izlem ve görüntüleme yöntemleri önemlidir. Çocuklarda görülen idrar yolu enfeksiyonlarının altında ürolojik bir sorunun varlığı her zaman düşünülmelidir.

\section{KAYNAKLAR}

1. Bensman A, Dunand O, Ulinski T. Urinary tract infection In:Avner ED, Harmon WE, Niaudet P. Yoshikawa N. (Eds). Pediatric Nephrology, 6th ed. Lippincott Williams-Wilkins, Baltimore 2009; 1299-1310.

2. Neyzi O, Ertuğrul T. Pediatri (4. baski) Nobel Tip Kitabevi, İstanbul. 2010; cilt:2, 1491-1495.

3. Alpay H, Karaaslan Bıyıklı N, Yenidoğanlarda İdrar Yolu Enfeksiyonu. Türk Nefroloji Diyaliz ve Transplantasyon Dergisi. 2005;14 (1) 1-4.

4. Tamim MM, Alesseh H, Aziz H. Analysis of the efficiency of urine culture as part of sepsis evaluation in the premature infant. Pediatr Infect Dis J 2003;22(9):805-8.

5. Dönmez O. Çocuklarda İdrar Yolu Enfeksiyonlarl, Güncel Pediatri $2003 ; 1: 50-58$.

6. Bratslavsky G, Feustel PJ, Aslan AR, Kogan BA.: Recurrence risk in infants with rinary tract infections and a negative radiographic evaluation. J Urol 2004 ct;172(4):1610-1613.

7. Yenidoğan Enfeksiyonları Tanı ve Tedavi Rehberi 2018. Türk Neonatoloji Derneği

8. Williams G, Craig JC. Diagnosisi and Management of Urinary Tract Infections.In: Geary DF, Schaefer F(Eds). Comprehensive Pediatric Nephrology.Philadelphia 2008,539-548.

9. Arshad M, Seed PC. Urinary tract infections in the infant. Clin Perinatol $2015 ; 42(1): 17-28$, vii.

10. Krober MS, Bass JW,Powell JM, Smith FR, Seto DSY: Bacterial and viral pathogens causing fever in infants less than 3 months old. Am J Dis Child, 1985; 139: 889-892.

11. Krasinski KM, Urinary Tract Infections. In: Gershon AA, Hotez PJ, Katz SL (Eds). Infectious Diseases of Children 11th edition Philadelphia 2004, 769-784.

12. Dayan PS, Hanson E, Benett JE, Langsam D, Miller SZ. Clinical course of urinary tract infections in infants younger than 60 days of age Pediatr Emeg Care 2004; 20: 85-89.

13. Bonadio $W$, Maida $G$. Urinary tract infection in outpatient febril infants younger than 30 days of age: a 10 year evaluation. Pediatr Infect Dis J 2014:33:342

14. Emamghorashi F, Mahmoodi N, Tagarod Z, Heydari ST. Maternal Urinary Tract Infection as a Risk Factor For Neonatal Urinary Tract Infection. IJKD. 2012;6;178-180.

15. Arıkan Fi், Çelikel B, Tıraş Ü et al. Yenidoğan İdrar yolu Enfeksiyonları. Bakırköy Tıp Dergisi. 2009;5.109-112.

16. Biyikli NK, Alpay H, Ozek E, Akman I, Bilgen H. Neonatal urinary tract infections: analysis of the patients and recurrences. Pediatr Int 2004; 46: 21-25.

17. Rahman AJ, Naz F, Ashraf S. Significance of pyuria in the diagnosis of urinary tract infections in neonates. J Pak Med Assoc. 2011;61:70-73.

18. Türkmen M, Özkan P, Aydoğdu SA. Yenidoğanlarda torba ve suprapubik aspirasyon yöntemi ile alınan idrar kültürü sonuçlarının karşılaştırılmast. Çocuk Sağlığı ve Hastalıkları Dergisi 2008; 51: 193-198.

19. Semerci N, Çalık A, Sönmez F, Eyigör M. Torba yöntemi ile idrar kültürü almanin güvenirliliği. 43. Türk Pediatri Kongresi, Antalya, 2007.

20. Honkinen O, Lehtonen OP, Ruuskanen O, Huovinen P, Mertsola J. Cohort study of bacterial species causing urinary tract infection and urinary tract abnormalities in children. BMJ 318:770-771.

21. Omar C, Hamza S, Bassem AM, Mairam R. Urinary tract infection and indirect hyperbilirubinemia in newborns. JMed Sci. 2011;3:544-547

22. Han YJ, Yu SL, Tao YZ. Urinary tract infections in the neonatal intensive care unit: clinical analysis of 229 cases. Zhanqquo Dang Dai Er Ke Za Zhi. 2012;14:177-180.

23. Hamburger EK. Urinary tract infections in infants and children. Postgraduate Med.1986; 80: 235-41. 